\title{
THE RATE OF INFILTRATION OF LATERITIC SOILS ${ }^{1}$
}

\section{J. A. Bonnet and M. A. Lugo López ${ }^{2}$}

\section{INTRODUCTION}

Lateritic soils are products of humid tropical weathering of rocks which are usually basic in reaction, resulting in acidic material high in free sesquioxides, low in free silica and exchange capacity, very permeable to water and air, and, in many instances, of great depth, but exhibiting little or no differentiation into soil horizons. They are generally found in regions with mean annual temperatures above $70^{\circ} \mathrm{F}$ and rainfall above 80 inches.

The red and yellow lateritic soils of the Tropics have a relatively rapid rate of percolation through their profiles and are easily worked after a rain. They are resistant to erosion as compared to other soils of similar climatic, relief and management conditions. This field behavior is peculiar because lateritic soils contain a high clay content or of particles whose diameter is less than 2 microns.

This paper presents data on the infiltration rate of lateritic soils o Puerto Rico and discusses the related physical factors.

\section{SoILs STudied}

Representative types were selected, of each of the lateritic great soil groups recognized in Puerto Rico (10), ${ }^{3}$ namely, Laterite, Reddish Brown Lateritic, and Yellowish Brown Lateritic. A typical Laterite occurs at the Las Mesas Plateau in western Puerto Rico. The topography is hilly and the underlying rock is serpentine, a product of the metamorphosis of pteridotite. The soil was classified by Roberts (10), as Nipe clay, following the one described in Cuba by Bennet and Allison (2). It is red and very deep, extending in many places down to 30 or 40 feet. The soil is more or less uniform in physical properties from the surface layer to bedrock. A characteristic feature is the presence in the profile of iron concretions of various sizes. The total exchange capacity ranges from 2 to 3 m.e. per $100 \mathrm{gm}$. of dry soil and gives the soil a poor capacity to retain available cation nutrients. Much care must be exercised in fertilization in order to avoid heavy nutrient losses. Nipe clay is a very poor agricultural soil, low in nitrogen and very low in available phosphorus, calcium, and potassium (3).

The Reddish Brown Lateritics are the most extensive group of lateritic soils in Puerto Rico. The largest area is planted to coffee but considerable

${ }^{1}$ Contribution from the Department of Soils, Agricultural Experiment Station, University of Puerto Rico, Río Piedras, P. R.

${ }^{2}$ Head of the Department of Soils and Associate Soil Scientist, respectively.

${ }^{3}$ Numbers in parentheses refer to Literature cited p. 166. 
areas are planted to pineapple, sugarcane, and other crops. Their exchange capacity ranges from 8 to 16 m.e. per $100 \mathrm{gm}$. of soil or about four to five times as large as that of the Laterite, but considerably lower than the more fertile soils of the Tropics (5). Catalina clay is typical of this group; it is very deep, strongly acid, red, friable, (4), and can be easily worked. The Catalina series is associated with the Cialitos, Alonso, Malaya, and other soil series of the humid hilly and mountain area of Puerto Rico. They are derived from tuffaceous volcanic rocks; their inherent fertility is moderate and they are low in available phosphorus and calcium. Alonso clay is very similar in physical and chemical characteristics to Catalina clay, but it is a more productive soil, largely planted to coffee. It can be readily identified by the brownish purple color throughout the profile. Alonso clay has been observed to be less plastic than its red lateritic associates. Matanzas clay is representative of a large extensive group of coastal plain reddish brown lateritic soils which include the Bayamón, Maleza, and other series. They are very valuable agricultural lands; well adapted to sugarcane or fruit growing and have been rated as moderately high in productivity. These soils occur along the north coast and are underlain by tertiary limestone formations. Río Piedras clay is a medium deep acid soil of the uplands, derived from ashy shales. It tends to be more plastic than the other lateritic soils. Its fertility is rather low. This soil is mostly planted to sugarcane and subsistence crops, but considerable portions of the shallower areas are in native pastures of very low carrying capacity.

Coto clay is a typical Yellowish Brown Lateritic soil representative of a rather inextensive group of soils occurring in northwest and northern Puerto Rico. The color is yellowish brown in the surface layer but gradually changes to light yellow with depth. It is acid throughout the profile until the underlying tertiary limestone rock is encountered. The depth to rock is very variable although on a typical profile it has been found at 5 feet. Coto clay is a very valuable soil for farming usually planted to a wide variety of such crops as sugarcane, truck crops, subsistence crops, and tobacco.

Recent mineralogical studies by Jeffries et al (8) indicate that kaolin is the clay mineral of lateritic soils, a fact that explains in part their low exchange capacity; the coarser fractions are almost free of feldspars, which give them their low inherent fertility.

\section{Methods}

The buffer-compartment method as outlined by Nelson and Muckenhirn was used (9). The procedure is as follows:

"Three concentric iron rings, each 5 inches in height and 9, 18, and 27 inches respectively in diameter, are driven into the ground 2 or 3 inch surface. The soil inside the two outside rings is kept saturated with water 
while the test is running. The infiltration test is run in the soil within the inner 9-inch ring, over which hangs a calibrated $2000 \mathrm{ml}$. burette, the water reservoir. A volume of $1,043 \mathrm{ml}$. in this burette is equivalent approximately to one inch of water added to the 9-inch soil core. A pinchcock serves as a valve at the rubber hose that connects the tip of this burette to a small glass tube. The burette is filled with water to the $2000 \mathrm{ml}$. mark and is stoppered. The stopcock is opened and the starting time is recorded. Water infiltrates rapidly at first, into the soil, until the thin film of water that collects on the top soil touches the end of the small tube. This film serves as a regulator for the water to run from the burette as fast as the soil requires it. The time is recorded every time the burette is emptied to the zero mark. At this time the pinchcock is closed rapidly and the burette is refilled with water. The outfit is kept covered with a canvas."

TABLE 1.-Mean infiltration rate per hour for six lateritic soils of Puerto Rico

\begin{tabular}{|c|c|c|c|c|c|c|c|c|c|}
\hline \multirow{2}{*}{ Soil type ${ }^{1}$} & \multirow{2}{*}{ Tests } & \multicolumn{8}{|c|}{ Mean rate of infiltration in inches per hour given- } \\
\hline & & 1 & 2 & 3 & 4 & 5 & 6 & 7 & 8 \\
\hline & $\begin{array}{c}\text { Num- } \\
\text { ber }\end{array}$ & Inches & Inches & Inches & Inches & Inches & Inches & Inches & Inches \\
\hline Nipe clay ${ }^{2}$. & 4 & 14.46 & 8.15 & 5.58 & 6.80 & 12.51 & 9.47 & 5.93 & 6.16 \\
\hline Río Piedras clay. & 8 & 31.44 & 13.88 & 10.47 & 10.15 & 10.85 & 8.12 & 7.57 & 7.83 \\
\hline Catalina clay .... & 20 & 9.79 & 6.78 & 5.96 & 5.44 & 5.15 & 4.02 & 4.37 & 4.16 \\
\hline Matanzas clay. & 4 & 23.76 & 15.01 & 11.76 & 10.05 & 7.67 & 7.09 & 6.67 & 5.88 \\
\hline Alonso clay. & 4 & 27.26 & 19.53 & 15.25 & 14.65 & 13.07 & 11.36 & 10.51 & 9.47 \\
\hline Coto clay. & 12 & 7.75 & 5.48 & 4.65 & 4.50 & 4.22 & 3.92 & 3.75 & 3.72 \\
\hline
\end{tabular}

1 Nipe clay is a Laterite, Coto clay is a Yellowish Brown Lateritic, and the others are Reddish Brown Lateritics.

${ }^{2}$ Test run in two 4 -hour periods for 2 successive days.

The test was run for 8 consecutive hours, except in the case of Nipe clay when two 4 -hour runs were made on two successive days. The amount of water used every hour was also recorded. Four replicated tests were run side-by-side for the same soil. Mechanical analyses were made by the Bouyoucos-hydrometer technique. Aggregate analysis were made by elutriation using the Kopecky type of apparatus (1).

\section{Presentation of Data}

The mean infiltration data for six lateritic soils of Puerto Rico, per hour, up to the eighth-hour run is reported in table 1 . The data represent the mean values obtained for 4 tests of the Laterite, Nipe clay, 36 tests of the Reddish Brown Lateritic group, and 12 for the Yellowish Brown Lateritic, Coto clay. The Reddish Brown Lateritic group includes 8 tests of Río Piedras clay, 20 of Catalina clay, 4 of Matanzas clay, and 4 tests of Alonso 
clay. The Yellowish Brown Lateritic group includes 12 tests of Coto clay.

The percentage of aggregates $(0.05$ to $2 \mathrm{~mm}$.) and total silt and clay (particles less than $0.05 \mathrm{~mm}$.) aggregated and not aggregated, are reported in table 2. The data for Nipe clay were obtained from the Soil Survey of Puerto Rico (10).

TABLE 2.-Aggregation analysis and total silt and clay contents of lateritic soils

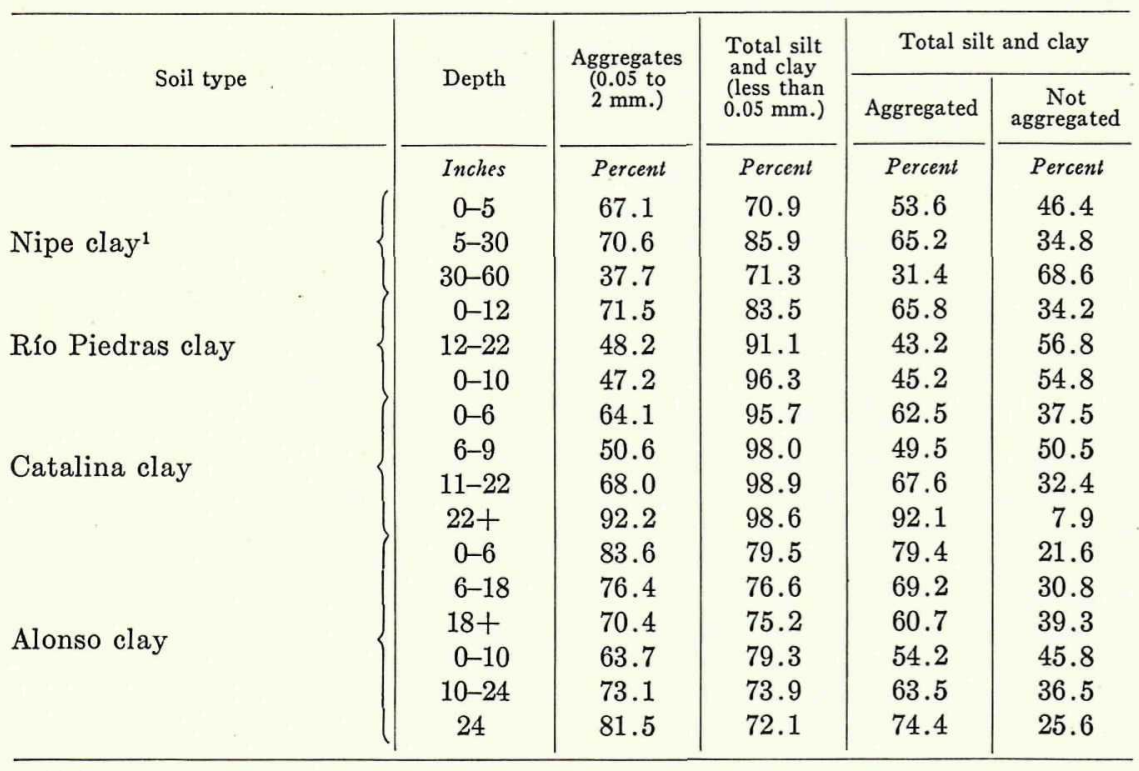

${ }^{1}$ Data reported by L. D. Baver, p. 475 Soil Survey of Puerto Rico (10).

\section{Discussion}

At the beginning of the tests considerable variation is apparent in the rate at which water penetrates the profile. Such variability can be ascribed to the differences in moisture content of the soil at the beginning of the run. Those differences are entirely beyond control since they are almost completely dependent on weather conditions at the time the tests are initiated. The fact that towards the end of the tests those differences are minimized further corroborates this point. At such time, the moisture level in the soils studied is on a more equalized basis and the infiltration rates are then more likely to be the result of soil characteristics than at the beginning. The similarities or differences at the last 3 or 4 hours can be explained on a basis of soil properties.

The mean infiltration rate of the water-saturated Laterite, Nipe clay, 
at the eighth-hour run was 6.16 inches (table 1), a very rapid infiltration rate $^{4}(6)$.

The mean infiltration rate of the Reddish Brown Lateritic group, at the eighth-hour run varied from 4.16 inches in the 20 tests of Catalina clay to 9.47 inches in 4 tests of Alonso clay. This group has also a very rapid infiltration rate. The mean value for the Río Piedras clay, Catalina clay, Matanzas clay, and Alonso clay, is 6.84 inches.

The mean infiltration rate of the Yellowish Brown Lateritic group, represented by Coto clay at the eighth-hour run, is also very rapid, 3.72 inches.

The aggregate analysis reported in table 2 is an aid for the study of soil structure relationships as pointed out by Baver and Rhoades: "From the physical point of view a soil may be pictured as being made up of mechanical and structural elements. The mechanical elements are the individual primary particles of various sizes, such as sand, silt, and clay. The structural elements are crumbs or granules of various dimensions which have been formed by the aggregation of the smaller mechanical elements. The extent to which a soil breaks up into crumbs or granules may be referred to as the state of aggregation of the soil."

The aggregates of particles above silt size $(0.05 \mathrm{~mm}$.) for the lateritic soils reported (table 2) vary from 37.7 to 92.2 percent; and the total silt and clay from 70.9 to 98.9 percent. From 31.4 to 92.1 percent of the total silt and clay is aggregated and 68.6 to 7.9 percent is not aggregated. The data show that the lateritic clays have a high state of aggregation.

It must be considered also that the clay content is a mixture of particles of true clay and of inert free sesquioxides of iron and aluminum that do not expand or contract as true clays. Bonnet (4) reported that a profile of Catalina clay of Puerto Rico contains 70 to 87 percent of total clay consisting of 45 to 61 percent of kaolinitic clay and 20 to 30 percent of free sesquioxides of $\mathrm{Fe}_{2} \mathrm{O}_{3}$ and $\mathrm{Al}_{2} \mathrm{O}_{3}$.

The high state of aggregation, content of inert free sesquioxides and the presence of a kaolinitic clay mineral that have limited contraction and expansion when the soil is dry or wet, respectively, are important physical factors that have a bearing in giving lateritic clays a high infiltration rate.

\section{SUMMARY}

Fifty-two infiltration tests were conducted on six soil types of Puerto Rico comprising three great soil groups: Laterite, Reddish Brown Lateritic, and Yellowish Brown Lateritic. The mean infiltration rate for the soils was very rapid, fluctuating from 3.72 to 9.47 inches per hour. This high

${ }^{4}$ A soil with more than 2.5 inches of water for the wet run has a very rapid rate of infiltration (6). 
infiltration rate is explained on the basis of a very high state of aggregation, the content of inert free sesquioxides, and the presence of kaolinitic type of clay in lateritic soils.

\section{RESUMEN}

Se hicieron 52 pruebas de infiltración en seis tipos de suelos lateríticos representados por los grupos Laterita, Suelos Lateríticos Pardo Rojizos, y Suelos Lateríticos Pardo Amarillentos. La velocidad de infiltración fué muy rápida y varió entre 3.72 y 9.47 pulgadas por hora. Esta velocidad rápida de infiltración se explica a base de una agregación alta de las partículas del suelo, del contenido de sesquióxidos libres de hierro y aluminio y de la presencia de una arcilla del tipo caolín, en los suelos lateríticos.

\section{Literature Cited}

1. Baver, L. D. and Rhoades, H. F., Aggregate analysis as an aid in the study of soil structure relationships; Jour. Am. Soc. Agron. 24 920-930, 1932.

2. Bennet, H. H. and Allison, R. V., The Soils of Cuba, Tropical Plant Research Foundation, Washington, D. C., 410 pp., 1928.

3. Bonnet, J. A., Chemical data of Puerto Rico Soils, University of Puerto Rico, Agric. Expt. Sta., Res. Bul. 1, 53 pp., 1941.

4. Bonnet, J. A., The nature of laterization as revealed by chemical, physical, and mineralogical studies of a lateritic soil profile from Puerto Rico, Soil Sc. 48 25-40, 1939.

5. Bonnet, J. A. and Lugo López, M. A., and Abruña, F., Cation exchange capacity of some tropical soils of Puerto Rico; Jour. of Agric. Univ. of P. R., 35(2) 49-56, April 1951.

6. Bonnet, J. A. and Lugo López, M. A., Aids used in interpreting soils data at the University of Puerto Rico, Paper presented to the Caribbean Soils Conference held in Puerto Rico, March-April, 1950; also p. 99 Soil Science in the Caribbean. Report of the Soils Conference held in Puerto Rico, March 30-April 8, 1950, 265 p. Caribbean Commission Central Secretariat, Kent House, Port of Spain, Trinidad, 1950.

7. Bonnet, J. A. and Lugo López, M. A., Relative erosiveness of Puerto Rico soils, Jour. of Agric. Univ. P. R., 34(3) 294-307, July 1950.

8. Jeffries, C. D., Bonnet, J. A., and Abruña, F., The constituent minerals of some soils of Puerto Rico, unpublished report Univ. of P. R., Agric. Expt. Sta., 1950.

9. Nelson, L. B. and Muckenhirn, R. J., Field percolation rates of four Wisconsin soils having different drainage characteristics, Jour. Am. Soc. Agron., 33 10281036, 1941.

10. Roberts, R. C., Soil Survey of Puerto Rico, U.S.D.A. Bur. of Plant Industry in cooperation with Univ. of Puerto Rico Agric. Expt. Sta., Series 1936, No. 8, 503 pp., 1942. 